\title{
Modern development trend of normative monetary valuation of non-agricultural land plots in Ukraine
}

\author{
Tetiana Anopriienko ${ }^{1, *}$, Maryna Pilicheva ${ }^{2}$, and Volha Sauchanka ${ }^{3}$ \\ ${ }^{1}$ Kharkiv National Agrarian University named after V. V. Dokuchaiev, Department of Planning of the Territory of Settlements and \\ Construction, Dokuchaevske-2, 62483, Ukraine \\ ${ }^{2}$ Kharkiv National Automobile and Highway University, Department of Highway Design, Geodesy and Land Management, 25 Yaroslava \\ Mudroho Str., Kharkiv, 61002, Ukraine \\ ${ }^{3}$ University of Cambridge, Department of Medicine, EMIT \& CCTU Division, level 6, ACCI building, box 110, Addenbrooke's hospital, \\ Hills road, Cambridge, CB2 0QQ, Great Britain
}

\begin{abstract}
The article identifies the main types of land valuation - expert monetary valuation for individual evaluation of particular plots and normative monetary valuation for systematic valuation of land for tax purposes. To conduct the last one, a mass assessment of land plots considering geoinformation technologies is used. It is established that at the present stage of normative monetary valuation of non-agricultural land plots in Ukraine two methodologies are used: within the settlement and outside it. The project of the unified methodology of normative monetary valuation of land plots by combining the existing methods submitted for discussion by the Ministry of Economy, Trade and Agriculture of Ukraine is considered. The values of land plots according to the existing and unified methodologies are studied on the example of four land plots under gas stations, which are located in the city of Kharkiv and outside it. It is established that the values of land plots, determined by existing and unified methods, differ both in the direction of increase and decrease, the difference varies from $9 \%$ to $97 \%$. It is necessary to conduct additional analysis of initial data and indicators, which are the basis for calculating and improve the offer unified methodology.
\end{abstract}

\section{Introduction}

Land valuation has recently become a mandatory component in land transactions [1], such as taxation, sale, withdrawal, consolidation [2], as well as in the field of land management, management of land resources [3] and State Land Cadastre management [4]. The value of land depends on physical, economic, social, environmental and legal factors [5]. As in other countries, there are two main concepts of land value - market (expert monetary valuation) and for taxation (regulatory monetary valuation) in Ukraine [6].

Expert monetary valuation of land is performed by an expert appraiser in the case of alienation and insurance, pledge, reorganization, bankruptcy or liquidation of the enterprise that owns the land, it is done by court decision [7]. The following methodological approaches are used [8]:

- capitalization of net operating or rental income (direct and indirect);

- comparison of sale prices of similar land plots;

- taking into account the cost of land improvements.

The expert appraiser uses a methodical approach, which is provided with complete information about the object of evaluation. But determining the exact and optimal approach is a difficult task due to the variation of factors that affect the assessment, so the value of the land is often perceived as contradictory and biased. In addition, there is a human factor that leads to an overestimation or decrease in the real value of the evaluated object. Despite these shortcomings, such a model for determining the value of land may be acceptable for individual assessment of particular plots.

Systematic assessment of all land plots included in the State Land Cadaster [4] is performed for taxation, determination of the amount of rent, alienation, land management and cadaster by conducting an assessment for taxation (in Ukraine analogue to the normative monetary assessment). It requires up-to-date data, clear consistency and transparency [9-11]. Therefore, in most countries of the world mass valuation of land using geoinformation technologies [12-19] is performed, which allows to automate the collection of factors influencing the assessment, to analyze them and the necessary calculations. The use of automatic estimation models has been popular for more than ten years in developed countries such as Sweden, Canada and the United States, and is becoming popular around the world [20].

There is also a tendency to form such automated land valuation systems in Ukraine, but it is only at the stage of creating a regulatory framework and improving the methodology of regulatory monetary valuation of land [21]. Therefore, it is important to study changes in the regulatory monetary valuation of land in Ukraine.

* Corresponding author: atatyanav2017@gmail.com 


\section{Changes in the regulatory framework for conducting regulatory monetary valuation of land}

Nowadays the assessment of agricultural land and nonagricultural land is carried out separately in accordance with the relevant Procedures and Methods [22-27] in Ukraine. At the same time, appraisal works were allocated separately within the settlement $[26,27]$ and outside it $[24,25]$ for non-agricultural land plots. The focus will be on non-agricultural land in the future, as they are the most common and their value (especially land for industrial, transport, communications, energy, defense and other) is quite high.

The normative monetary valuation for nonagricultural land plots within a settlement is based on the capitalization of the rent income of the settlement. The main stages of determining the value of non-agricultural land within the settlement are shown in Figure 1 according to the procedure [26].

The cost of one square meter of land of a certain functional use $(\mathrm{Cn})$ is determined taking into account the territorial planning, engineering-geological, historicalcultural, natural-landscape, sanitary-hygienic and engineering-infrastructural features of its location within the economic-planning zone according to the formula (1) [26]:

$$
\mathrm{Cn}=\mathrm{Cnz} \cdot \mathrm{Kf} \cdot \mathrm{Km} 3 \text {. }
$$

The value of the coefficient $\mathrm{Km} 3$ is determined for an individual land plot on the basis of determining the share of the area occupied by the factor on the land plot. The share of the area is established mainly through the use of GIS technologies and electronic digital maps.

Normative monetary valuation of non-agricultural lands within the settlement

The average base cost of one square meter of land of the settlement depending on regional factors of a location $(\mathrm{Cnm})$

The cost of one square meter of land in settlements by economic planning zones $(\mathrm{Cnz})$

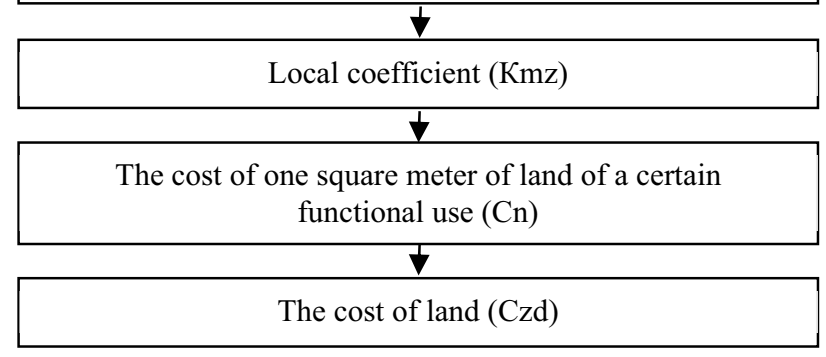

Fig. 1. Stages of determining the value of non-agricultural land within the settlement.
Normative monetary valuation of non-agricultural land outside the settlement is based on the norm of rental income and is determined by formula (2) [24]:

$$
\mathrm{Cn}=\mathrm{Pd} \cdot \mathrm{Rd} \cdot \mathrm{Sc} \cdot \mathrm{Km} \cdot \mathrm{Kv} \cdot \mathrm{Kmc} \cdot \mathrm{Ki}
$$

where Pd - area of the land plot accepted according to the data of the State Land Cadaster or land management documentation, $\mathrm{m}^{2}$;

$\mathrm{Rd}$ - rental income per $\mathrm{m} 2$ of area for the relevant category of land, determined by the standards of rental income for the relevant category of land, UAH / year;

$\mathrm{Sc}$ - term of capitalization, years;

$\mathrm{Km}$ - coefficient that takes into account the location of the land;

$\mathrm{Kv}$ - coefficient that takes into account the type of land use;

$\mathrm{Kmc}$ - coefficient that takes into account the affiliation of the land to the lands of environmental, health, recreational, historical and cultural purposes;

$\mathrm{Ki}$ - indexation coefficient of the normative monetary valuation of lands.

According to the project of Normative monetary valuation methodology of land plots [21], it is offered to create a single valuation procedure for all land plots, regardless of their purpose and location relative to the settlement. But this takes into account the boundaries of the territorial community.

Normative monetary valuation of land $(\mathrm{Cn})$ is determined by formula (3):

$\mathrm{Cn}=\mathrm{Pd} \cdot \mathrm{Nrd} \cdot \mathrm{Km} 1 \cdot \mathrm{Km} 2 \cdot \mathrm{m} 3 \cdot \mathrm{Km} 4 \cdot \mathrm{Kcp} \cdot \mathrm{Kmc} \cdot \mathrm{Kni},(3)$

where $\mathrm{Pd}$ - land area, $\mathrm{m}^{2}$;

$\mathrm{Nrd}$ - the rate of capitalized rental income per unit area;

$\mathrm{Km} 1$ - coefficient that takes into account the location of the community within the zone of influence of large cities;

$\mathrm{Km} 2$ - coefficient that takes into account the resort and recreational value of settlements;

$\mathrm{Km} 3$ - coefficient that takes into account the location of the community within the zones of radiation pollution;

$\mathrm{Km} 4$ - coefficient that characterizes the zonal factors of the location of the land;

Kcp - coefficient that takes into account the purpose of the land in accordance with the State Land Cadastre;

$\mathrm{Kmc}$ - coefficient that takes into account the peculiarities of land use within the category of land for the main purpose;

$\mathrm{Kni}$ - the product of the indexation coefficients of the normative monetary valuation of land for the period from the approval of the standard of capitalized rental income to the date of the valuation.

The application of the project Methodology [21] will unify the cadastral information exchange file (XML-file), which is used to enter information in the State Land Cadaster [4], and apply automated methods of calculating the value of land using data from the State Land Cadaster. 


\section{Investigation of changes in the value of non-agricultural land plots using a unified methodology}

To study the change in the value of non-agricultural land plots using a unified method of calculating the normative monetary valuation, land plots with gas stations are selected and information about which is freely available on the Public Cadastral Map of Ukraine [28] (Fig. 2).

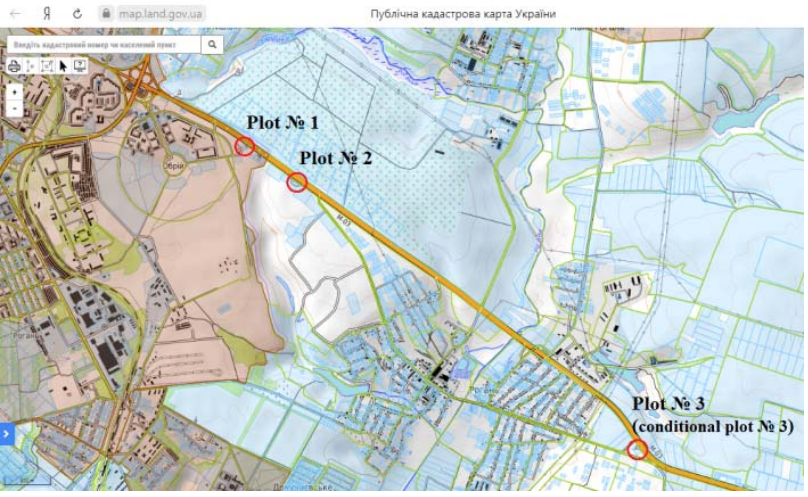

Fig. 2. Layout of land plots (according to the State Land Cadastre) [28].

Land plot № 1 (cadastral number 6310138200:10:015:0003) is located on the outskirts of the regional center - the city of Kharkiv (Fig. 2). The plot has a total area of $2682 \mathrm{~m}^{2}(0.2682 \mathrm{ha})$ and is privately owned. It is located along the highway of state importance M-03 Kyiv - Kharkiv - Dovzhansky (to the city of Rostov-on-Don) (Kharkiv - Rostov-on-Don (M19)) at a distance of $250 \mathrm{~m}$ from the eastern border of Kharkiv (Fig. 3).

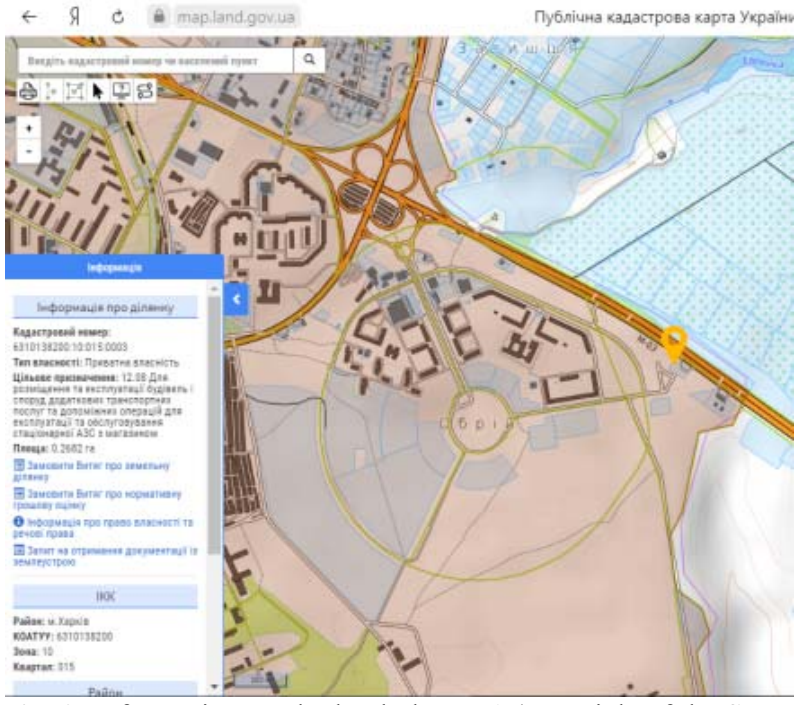

Fig. 3. Information on the land plot № 1 (materials of the State Land Cadaster - data of the Public Cadastral Map of Ukraine) [28].

Land plot № 2 (cadastral number 6325182500:02:005:0005) is located near the border of the regional center - the city of Kharkiv on the territory of Vilkhiv united territorial community within Maloroganska village council, Kharkiv district, Kharkiv region (Fig. 4). The plot with a total area of $10000 \mathrm{~m}^{2}(1.0000 \mathrm{ha})$ is state-owned. It is located along the state highway M-03 Kyiv - Kharkiv - Dovzhansky (to the city of Rostov-on-Don) (Kharkiv - Rostov-onDon (M19)) at a distance of $350 \mathrm{~m}$ from the eastern border of Kharkiv. The distance between sections № 1 and № 2 is $560 \mathrm{~m}$ on the highway, between sections № 2 and № 3-4600 $\mathrm{m}$ on the highway (Fig. 2).

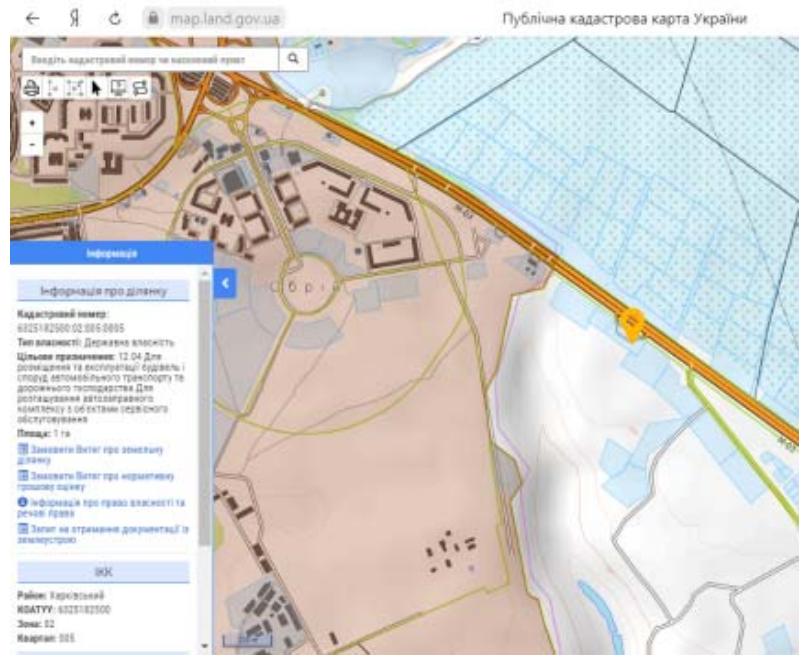

Fig. 4. Information on the land plot № 2 (materials of the State Land Cadaster - data of the Public Cadastral Map of Ukraine) [28].

Land plot № 3 (cadastral number 6325158500:01:041:0005) is located at a distance of $\mathrm{km}$ from the eastern border of the regional center - the city of Kharkiv on the territory of Rogan united territorial community within Rogan village council, Kharkiv district, Kharkiv region (Fig. 2). The plot with a total area of $5270 \mathrm{~m}^{2}(0.5270 \mathrm{ha})$ is state-owned. Located outside the village of Rogan near its eastern border (in the direction of Chuguev), along the highway of state importance M-03 Kyiv - Kharkiv - Dovzhansky (to the city of Rostov-on-Don) (Kharkiv - Rostov-onDon) (M19)) (Fig. 5).

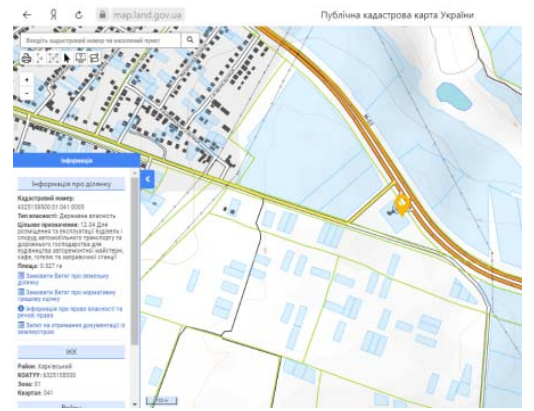

Fig. 5. Information on the land plot № 3 (materials of the tate Land Cadastre - data of the Public Cadastral Map of Ukraine) [20]

For investigation the conditional plot № 3 will be taken, which has the same characteristics as the land plot № 3, but is located within the settlement of Rohan village with the conditional cadastral number 6325158500:00:005:0000 (Fig. 2). 
According to the existing regulatory framework and Figure 1, the calculations of the normative monetary valuation of land plots № 1 and № 3 are conditional, as plots are located within the settlements (Table 1). Indicators of the base value of $1 \mathrm{~m}^{2}$ of land of the respective settlements are taken according to the data posted on the official website of the State Service of Ukraine for Geodesy, Cartography and Cadaster (State Geocadaster of Ukraine) [29]. According to the purpose of further analysis and comparison of indicators of estimation of data reduction we will carry out with base cost of $1 \mathrm{~m}^{2}$ of land plots of the settlement for 01.01.2020, that's why the indexing factor $(\mathrm{Ki})$ is applied.

According to the calculations of the normative monetary valuation of land plots of same definite purpose, which are located along one highway of state importance on the outskirts of settlements at a distance of about $5 \mathrm{~km}$, the cost of $1 \mathrm{~m}^{2}$ of land located within the regional center - Kharkiv almost five times more than the cost of $1 \mathrm{~m}^{2}$ of land located within the neighboring village of Rogan (Table 1).

Land plots № 2 and № 3 are located outside the settlements along one highway of state importance, but on the territory of the neighboring united territorial communities (Vilkhivska and Rohanska). According to formula 2 the normative monetary valuation of land plots № 2 and № 3, which are located outside the settlements (Table 2) can be calculated.

According to the calculations of the normative monetary valuation of land plots of one purpose, which are located along one highway of state importance outside the settlements, the cost of $1 \mathrm{~m}^{2}$ of land № 2 located closer to the regional center - the city of Kharkiv is almost $13 \%$ higher than the cost of $1 \mathrm{~m}^{2}$ of land plots № 3, due to the coefficient, which takes into account the location of lands.

The next step is to calculate the normative monetary valuation of four land plots of the same purpose, which are located along one highway of state importance within and outside the settlements according to the draft methodology of normative monetary valuation of land plots [21] (formula 3). In order not to distort the results of the assessment, the coefficient that characterizes the zonal factors of the location of the land plot $(\mathrm{Km} 4)$ is taken equal to 1 for all land plots. The results of the calculation of the normative monetary valuation of four nonagricultural land plots within and outside the settlements (under the gas station) according to the Project Methodology 2020 [21] are shown in Table 3.

Table 1. Normative monetary valuation of land plots within settlements (under the gas stations).

\begin{tabular}{|c|l|c|c|}
\hline \multirow{2}{*}{ Indicator } & \multicolumn{1}{|c|}{ Characteristics } & \multicolumn{2}{c|}{ Value } \\
\cline { 3 - 4 } & & plot № 1 & Conditional plot № 3 \\
\hline $\mathrm{Pd}$ & Land area, $\mathrm{m}^{2}$ & 2682 & 5270 \\
\hline $\mathrm{Cnm}$ & Base coat $1 \mathrm{~m}^{2}$, UAH (for 01.01.2020) & 639,78 & 131,63 \\
\hline $\mathrm{Km} 1$ & Regional location ratio & 3 & 1,5 \\
\hline $\mathrm{Kf}$ & Functional utilization coefficient & 2,5 & 2,5 \\
\hline $\mathrm{Km} 2$ & Coefficient, which concerns the degree of urban value & 1 & 1 \\
\hline $\mathrm{Km} 3$ & Local coefficients for the location of land & 0,87 & 0,87 \\
\hline $\mathrm{Cn}$ & Monetary value 1 $\mathbf{m}^{\mathbf{2}}$ of land, UAH & $\mathbf{1 3 9 1 , 5 2}$ & $\mathbf{2 8 6 , 3 0}$ \\
\hline Czd & Monetary value of land plot, UAH & $\mathbf{3 7 3 2} \mathbf{0 5 6 , 6 4}$ & $\mathbf{1 ~ 5 0 8 ~ 8 0 1 , 0 0}$ \\
\hline
\end{tabular}

Table 2. Calculation of the normative monetary valuation of non-agricultural land outside settlements (under the gas stations).

\begin{tabular}{|c|c|c|c|}
\hline \multirow{2}{*}{ Indicator } & \multirow{2}{*}{ Characteristics } & \multicolumn{2}{|c|}{ Value } \\
\hline & & plot № 2 & plot № 3 \\
\hline $\mathrm{Pd}$ & Land area, $\mathrm{m}^{2}$ & 10000 & 5270 \\
\hline $\mathrm{Rd}$ & Rent income per $1 \mathrm{~m}^{2}$ area of relevant land category, UAH/year & 0,6637 & 0,6637 \\
\hline $\mathrm{Sk}$ & Capitalization period, years & 33 & 33 \\
\hline $\mathrm{Km}$ & Coefficient of land location & 5,1708 & 4,5679 \\
\hline $\mathrm{Kv}$ & Coefficient of land usage & 2,9750 & 2,9750 \\
\hline $\mathrm{Kmc}$ & $\begin{array}{l}\text { Coefficient of land belonging to natural security, recreational, historical, health or cultural } \\
\text { objects }\end{array}$ & 1 & 1 \\
\hline $\mathrm{Ki}$ & Indexation coefficient of normative monetary valuation of land & 1,8972 & 1,8972 \\
\hline Cn1 & Normative monetary value of $1 \mathrm{~m}^{2}$ of land, UAH/m² & 639,21 & 564,68 \\
\hline Cn & Normative monetary value of land plot, UAH & 6392100,00 & 2975863,60 \\
\hline
\end{tabular}

According to the results of calculations of the normative monetary valuation of four non-agricultural land plots within and outside settlements (under gas stations) according to the Project Methodology 2020 [21], the cost of $1 \mathrm{~m}^{2}$ of land plot located within the regional center Kharkiv is the highest. The cost of $1 \mathrm{~m} 2$ of land № 2, which is located closest to the regional center - the city of Kharkiv $(350 \mathrm{~m})$ and at a distance from the site № $1-560 \mathrm{~m}$ is 4.75 times less than the cost of $1 \mathrm{~m}^{2}$ of land № 1, and 1,53 times less than the value of $1 \mathrm{~m}^{2}$ of land № 3 and 1.68 times less than the value of $1 \mathrm{~m}^{2}$ of conditional plot № 3. The results of comparing the calculations of the normative monetary valuation of four non-agricultural land plots within and outside settlements (under gas stations) according to the current methods [25, 27] and the project Methodology 2020 [21] are shown in Figure 5. According to the results of calculations the regulatory monetary value of land № 1 will increase in 2021 by $15 \%$.

However, the regulatory monetary value of land № 2 will decrease in 2021 by almost half $(47 \%)$. This is due to the value of the capitalized rental income ratio, which 
is determined depending on the population in the settlement, which is the administrative center of the community. A slight decrease in the regulatory monetary value in 2021 is projected for land plot № 3 - by $9 \%$. And for the conditional land plot № 3 it is possible to increase the normative monetary assessment in 2021 almost twice (by $97 \%$ ), which is partly due to the use when calculating the base value of $1 \mathrm{~m}^{2}$ of land of the settlement (Rogan village) according to the land valuation settlements held in 2009 .

Table 3. Calculation of the normative monetary valuation of non-agricultural land outside settlements (under the gas stations) according to the Project Methodology 2020 [21].

\begin{tabular}{|c|l|c|c|c|c|}
\hline \multirow{2}{*}{ Indicator } & \multicolumn{1}{|c|}{ Characteristics } & \multicolumn{3}{c|}{ Value } \\
\cline { 3 - 5 } & & plot № 1 & plot № 2 & plot No 3 & $\begin{array}{c}\text { conditional plot } \\
\text { № 3 }\end{array}$ \\
\hline $\mathrm{Pd}$ & Land area, $\mathrm{m}^{2}$ & 2682 & 10000 & 5270 & 5270 \\
\hline $\mathrm{Nrd}$ & Rate of capitalized rental income per unit of area & 639 & 87 & 133 & 133 \\
\hline $\mathrm{Km} 1$ & $\begin{array}{l}\text { Location coefficient of the community within the area of } \\
\text { influence of large cities }\end{array}$ & 1 & 1,3 & 1,3 & 1,3 \\
\hline $\mathrm{Km} 2$ & Resort and recreational value coefficient of settlements & 1 & 1 & 1 & 1 \\
\hline $\mathrm{Km} 3$ & $\begin{array}{l}\text { Location of the community within the areas of radiation } \\
\text { pollution coefficient }\end{array}$ & 1 & 1 & 1 & 1 \\
\hline $\mathrm{Km} 4$ & Zonal factors coefficient of the land location & 1,000 & 1,000 & 1,000 & 1,000 \\
\hline $\mathrm{Kcp}$ & Land purpose coefficient & 2,5 & 2,5 & 2,5 & 2,5 \\
\hline $\mathrm{Kmc}$ & $\begin{array}{l}\text { Peculiarities of land use coefficient within the category of } \\
\text { land for the main purpose }\end{array}$ & 1,001 & 1,19 & 1,19 & 1,304 \\
\hline $\mathrm{Kni}$ & $\begin{array}{l}\text { Product of coefficients' indexation of normative monetary } \\
\text { valuation of lands }\end{array}$ & 1,000 & 1,000 & 1,000 & 1,000 \\
\hline $\mathrm{Cn} 1$ & Normative monetary value of 1 m ${ }^{2}$ of land & $\mathbf{1 ~ 5 9 9 , 1 0}$ & $\mathbf{3 3 6 , 4 7}$ & $\mathbf{5 1 4 , 3 8}$ & $\mathbf{5 6 3 , 6 5}$ \\
\hline $\mathrm{Cn}$ & Normative monetary value of land & $\mathbf{4 2 8 8 ~ 7 8 6 , 2 0}$ & $\mathbf{3 ~ 3 6 4 ~ 7 0 0 , 0 0}$ & $\mathbf{2 ~ 7 1 0 ~ 7 8 2 , 6 0}$ & $\mathbf{2 9 7 0 ~ 4 3 5 , 5 0}$ \\
\hline
\end{tabular}

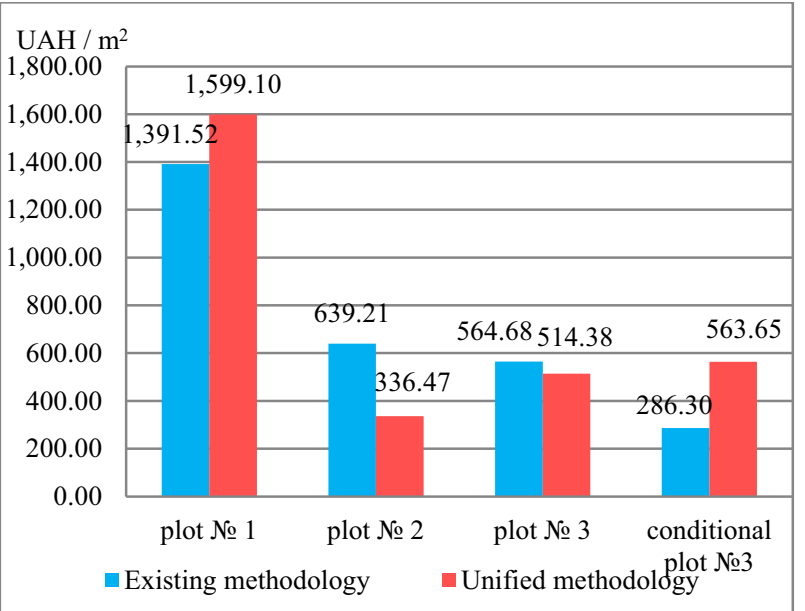

Fig. 5. The results of comparing the calculations of the normative monetary valuation according to the current methods [25, 27] and the project Methodology 2020 [21]

\section{Conclusions}

1. Works on land valuation do not lose relevance.

2. The use of geographic information technologies in the implementation of land valuation works create preconditions for the development and improvement of both land valuation works and the convenience of using its results by various entities.

3. The unified approach to the normative monetary valuation of land, offered by The Ministry of Economic Development, Trade and Agriculture of Ukraine, increases the convenience and improves the quality of land valuation work as a source of filling the State Land Cadaster with reliable data.
4. These calculations prove the need to analyze the initial data and indicators that underlie the calculations of the normative monetary valuation of land and further improvement of the proposed approach, in order to establish the fair value of all land.

\section{References}

1. J.C. Bencure, N.K. Tripathi, H. Miyazaki, S. Ninsawat, S.M. Kim, Development of an Innovative Land Valuation Model (iLVM) for Mass Appraisal Application in Sub-Urban Areas Using AHP: An Integration of Theoretical and Practical Approaches. Sustainability 11(13), 3731 (2019)

2. ELD Initiative. The Value of Land: Prosperous Lands and Positive Rewards through Sustainable Land Management. https://www.eld-initiative.org (2015). Accessed 15 June 2015

3. M.A. Omari, The Role of Reliable Land Valuation Systems in Land Management and Land Administration Systems efficiency, in FIG Working Week 14-19 June 2008: Integrating Generations; FIG (International Federation of Surveyors). Stockholm, Sweden (2008)

4. Procedure for conducting the State Land Cadastre: Resolution of the Cabinet of Ministers of Ukraine No. 1051. http://zakon.rada.gov.ua/laws/show/10512012-ח\#n19 (2012). Accessed 17 Oct 2020

5. P. Dale, J. McLaughlin, Land Administration (Oxford University Press, New York, 2003)

6. G. Milevski, Mass valuation of commercial real estate for taxation \& balance sheet purposes. https://www.diva-portal.org/smash/get/ 
diva2:305542/FULLTEXT02 (2009). Accessed 09 May 2020

7. On land valuation: Law of Ukraine No. 1378-IV. https://zakon.rada.gov.ua/laws/show/1378-15\#Text (2003). Accessed 11 Dec 2003

8. On expert monetary valuation of land plots: Resolution of the Cabinet of Ministers of Ukraine No. 1531. https://zakon.rada.gov.ua/laws/show/15312002-\%D0\%BF\#Text (2002). Accessed 11 Oct 2002

9. I.V. Koshkalda, T.V. Anopriienko, Improving the model of state regulation of monetary valuation of land. Economics of agro-industrial complex 12, 6-15 (2018)

10. T.V. Anopriienko, Features of information support of monetary valuation of land plots in the context of state regulation. Bulletin of Sumy National Agrarian University. Series: Economics and Management 6, 7$11(2018)$

11. T.V. Anopriienko, Qualitative information support of monetary valuation of lands is a way to form the real value of lands of different purpose and use. Urban planning and spatial planning 67, 27-38 (2018)

12. C. Hughes, S. Sayce, E. Shepherd, P. Wyatt, Implementing a land value tax: Considerations on moving from theory to practice. Land Use Policy 94, 104494 (2020) doi:10.1016/j.landusepol.2020.104494

13. B. Needham, Land taxation, development charges, and the effects on land-use. Journal of Property Research 17(3), 241-257 doi:10.1080/09599910050120000

(2020)

14. D.C. Sanderson, F. Shakurina, J. Lim, The impact of sale and leaseback on commercial real estate prices and initial yields in the UK. Journal of Property Research 36(3), 245-271

(2019) doi:10.1080/09599916.2019.1642370

15. S.E. Tione, S.T. Holden, Urban proximity, demand for land and land shadow prices in Malawi. Land Use $\begin{array}{llll}\text { Policy } & 94 & & \end{array}$ doi:10.1016/j.landusepol.2020.104509

16. M. Bogataj, D.T. Suban, S. Drobne, Regression-fuzzy approach to land valuation. Cent. Eur. J. Oper. Res. 19, 253-265 (2011)

17. J.M. Herrerias, R. Herrerias, Valuation method for land pricing based on two cumulative distribution functions. Span. J. Agric. Res. 8, 538-546 (2010)

18. R. Schulz, M. Wersing, A. Werwatz, Automated valuation modelling: A specification exercise. J. Prop. Res. 31, 131-153 (2014)

19. S. Yalpir, Enhancement of parcel valuation with adaptive artificial neural network modeling. J. Artif. Intell. Rev. 4, 1-13 (2016)

20. D. Demetriou, The assessment of land valuation in land consolidation schemes: The need for a new land valuation framework. Land Use Policy 54, 487-498 (2016)

21. Draft Resolution of the Cabinet of Ministers of Ukraine «On Approval of the Methodology of Normative Monetary Valuation of Land Plots».
https://www.me.gov.ua/Documents/ Detail?lang=ukUA\&id=4d00c4b8-d59a-4578-97e3-

a6452babf37b\&title=ProektPostanoviKabinetuMinist rivUkrainiproZatverdzhenniaMetodikiNormativnoiG roshovoiOtsinkiZemelnikhDilianok (2020). Accessed 13 Apr 2020

22. Procedure of normative monetary valuation of agricultural lands: Order of the Ministry of agricultural policy and food of Ukraine No. 262. https://zakon.rada.gov.ua/laws/show/z0679-17\#Text (2017). Accessed 23 May 2017

23. Methodology of normative monetary valuation of agricultural lands: Resolution of the Cabinet of Ministers of Ukraine No. 831. https://zakon.rada.gov.ua/laws/show/831-2016\%D0\%BF\#Text (2016). Accessed 16 Nov 2016

24 . Procedure for normative monetary valuation of nonagricultural lands (except for settlements): approved by the Order of the Ministry of Agricultural Policy and Food of Ukraine No. 508. http://zakon4.rada.gov.ua/laws/show/z157313/print1360517383069506 (2013). Accessed 22 Aug 2020

25. Methodology of normative monetary valuation of non-agricultural lands (except for settlements): approved by the Resolution of the Cabinet of Ministers of Ukraine No. 1278. http://zakon3.rada.gov.ua/laws/show/1278-2011-ח (2011). Accessed 23 Nov 2020

26. Procedure for the normative monetary valuation of the settlement lands: approved by the Order of the Ministry of Agricultural Policy and Food of Ukraine No. 489. http://zakon.rada.gov.ua/laws/show/z164716 (2016). Accessed 25 Nov 2020

27. Methodology of normative monetary valuation of settlement lands: approved by the Resolution of the Cabinet of Ministers of Ukraine No. 213. http://zakon.rada.gov.ua/laws/show/213-95-п (1995) Accessed 23 Mar 2021

28. Public cadastral map of Ukraine https://map.land.gov.ua/?cc=4061303.122204792,64 $31890.609380657 \& z=14 \& 1=$ atu, kadastr\&bl=dzk_ove rview_test (2020). Accessed 12 Feb 2020

29. Official site of the State Service of Ukraine for Geodesy, Cartography and Cadastre. https://land.gov.ua/ (2020). Accessed 14 Nov 2020 